\title{
Superficial venous thrombosis in Behçet's disease: a case report and a review of the literature
}

This article was published in the following Dove Press journal: Journal of Vascular Diagnostics and Interventions

\section{Mohammed El Amine Ghembaza',2 \\ Ali Lounici ${ }^{1,2}$}

'Department of Internal Medicine, Hospital University Tidjani Damerdji, Tlemcen, Algeria; ${ }^{2}$ Faculty of Medical Sciences, University of Abou Bekr Belkaid, Tlemcen, Algeria

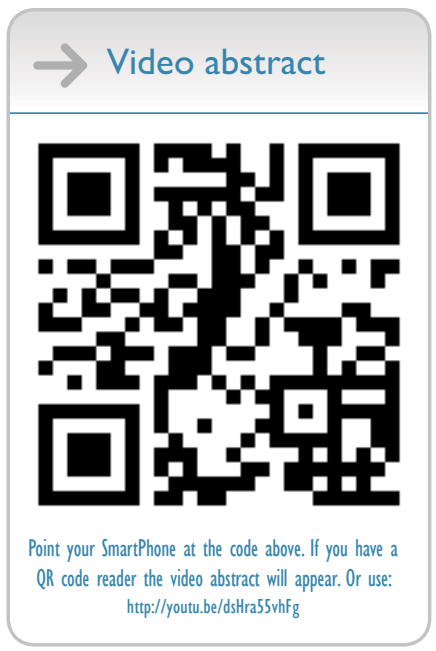

Correspondence: Mohammed El Amine Ghembaza

University of Abou Bekr Belkaid, 05, Bd Mohammed V, Tlemcen, 13000, Algeria $\mathrm{Tel}+21343417240$

Email amineghembaza@gmail.com

\begin{abstract}
Behçet's disease is a relapsing-remitting vasculitis that affects both arterial and venous vessels of various sizes. A 48-year-old man with Behçet's disease was seen at the outpatient clinic of our hospital for painful lesions on his left leg. Physical examination showed two tender erythematous linear indurations on the medial side of the left thigh and calf, of about $3 \mathrm{~cm}$ and $10 \mathrm{~cm}$ in length, respectively. Duplex ultrasonography revealed echogenic material in the lumen of collateral superficial veins, with no extension to the deep venous system. The patient was started on once-daily subcutaneous low-molecular-weight heparin in combination with elastic compression stockings, with spectacular improvement. Superficial venous thrombosis is a common manifestation of Behçet's disease, and the diagnosis is based on clinical features. Superficial venous thrombosis has a dual prognostic value: on one hand, it should raise the suspicion of concomitant deep venous and/or arterial involvement, and on the other hand, it may predict the development of future severe visceral manifestations.
\end{abstract}

Keywords: Behçet's disease, vasculitis, vascular involvement, venous thrombosis, superficial vein thrombosis

\section{Introduction}

Behçet's disease (BD) is a relapsing-remitting vasculitis that affects both arterial and venous vessels of various sizes. Recurrent bipolar ulcers and uveitis are the hallmark signs of the disease. However, other parts of the body may be affected, such as joints, vessels, brain, and gastrointestinal tract. ${ }^{1}$ Herein, we present a case of multiple superficial venous thrombosis (SVT) as a relapsing form of BD. We then provide a review of the literature, which was performed to summarize the present state of knowledge on SVT in BD.

\section{Case report}

A 48-year-old man with BD was seen at the outpatient clinic of our hospital for painful lesions on his left leg. The patient's medical history included BD with both venous and arterial manifestations, for which he had received cyclophosphamide followed by azathioprine.

The diagnosis of BD had been made 17 years earlier based on recurrent oral and genital ulcers, typical cutaneous lesions, and both arterial thrombosis and deep venous thrombosis (DVT) of the lower extremities. Physical examination showed two tender erythematous linear indurations on the medial side of the left thigh and calf. The lesions were about $3 \mathrm{~cm}$ and $10 \mathrm{~cm}$ in length, respectively, and multiple varicosities were seen in both legs (Figures 1 and 2). Oral, genital, dermatological, and neurological 
examination showed no active signs of the disease. Duplex ultrasonography revealed echogenic material in the lumen of collateral superficial veins, with no extension to the deep venous system. The patient was started on once-daily subcutaneous low-molecular-weight heparin in combination with elastic compression stockings, with spectacular improvement.

\section{Discussion}

Vascular manifestations of BD are reported to occur in up to $40 \%$ of patients. ${ }^{2}$ In our experience, vascular features are

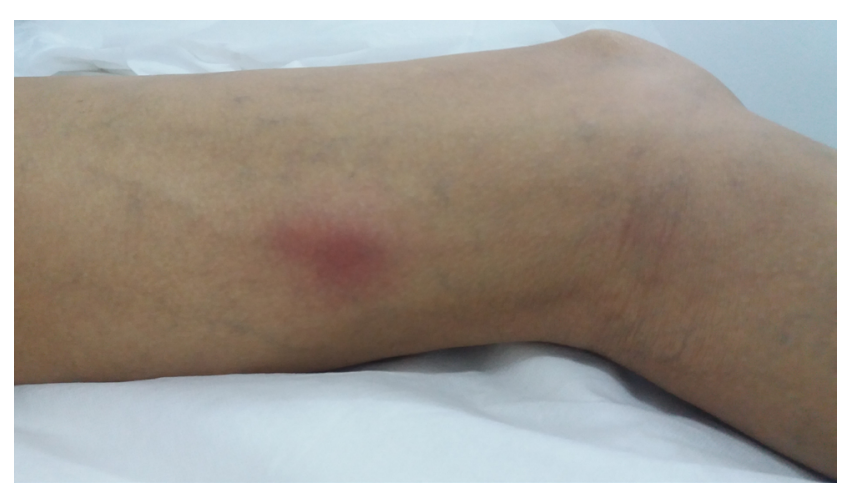

Figure I Superficial venous thrombosis on the left thigh.

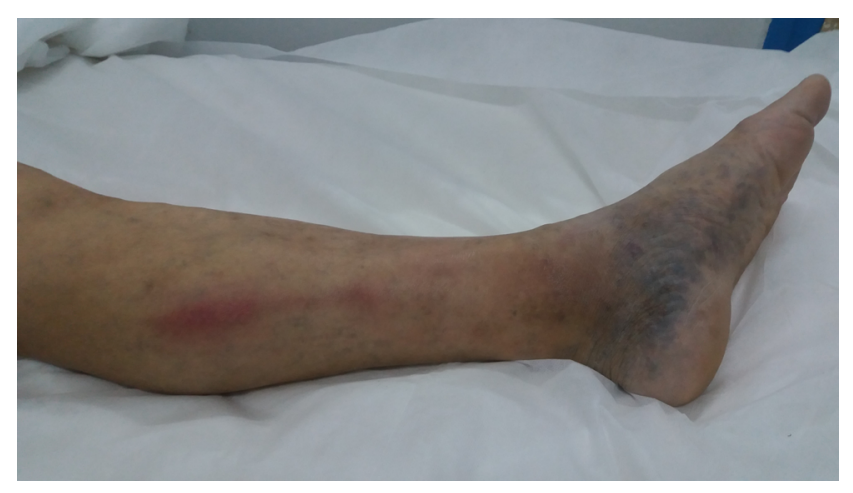

Figure 2 Superficial venous thrombosis on the left calf. seen in $30 \%$ of cases. ${ }^{3}$ The most common scenario is lower extremity DVT. It usually occurs in the early clinical course of the disease, often within the first few years. ${ }^{2}$

SVT is the second most common vascular manifestation of BD. ${ }^{4}$ The prevalence of SVT in BD has been reported at rates ranging from $2.1 \%$ to $53.3 \%$ (Table 1 ) ${ }^{5-16}$ with a definite male predominance. Usually, it occurs early in the second decade of life. ${ }^{17}$ The classical presentation is an erythematous, painful, string-like lesion extending along a superficial vein, which usually occurs on the lower extremities. Physical examination reveals a palpable cord, which is erythematous, tender and warm, with a surrounding edema. Thus, the diagnosis is usually obvious, based on clinical features. SVT typically occurs in varicose veins (chronic venous insufficiency), but can occur in nonvaricose veins. Duplex ultrasound is performed to assess the length of the thrombosis and to rule out a concomitant DVT. ${ }^{18}$

The greater saphenous vein and the small saphenous vein are by far the most affected segments. ${ }^{19}$ Sometimes, SVT occurs after a venipuncture or at the site of heparin injection, and thus it is considered as a vascular pathergy test. ${ }^{4}$ Some reports have shown that SVT may harbor an acquired or inherited thrombophilia such as positive anticardiolipin antibodies, but in the majority of cases, no triggering factor is found. ${ }^{20}$ Usually, SVT resolves spontaneously over 2-4 weeks, but in some cases, a post-inflammatory skin hyperpigmentation may last for several months. ${ }^{21}$

As shown in Table 1, it seems that DVT is more common than SVT in BD. However, other studies have shown a more frequent occurrence of SVT over DVT. ${ }^{5,11}$ These conflicting data may be partly explained by the fact that some authors included SVT in dermatological manifestations of BD and, thus, patients with ST were excluded from studies reporting the prevalence of vascular features in BD. Moreover, as SVT resolves spontaneously within a few days, it may be under-

Table I Prevalence of SVT related to BD in the literature

\begin{tabular}{|c|c|c|c|c|c|c|}
\hline Authors & Country & $\begin{array}{l}\text { Sample } \\
\text { size }\end{array}$ & $\begin{array}{l}\text { Diagnosis } \\
\text { criterion }\end{array}$ & $\begin{array}{l}\text { Vascular } \\
\text { involvement, } \mathbf{n}(\%)\end{array}$ & SVT, n (\%) & DVT, n (\%) \\
\hline Sarica-Kucukoglu et a $\left.\right|^{5}$ & Turkey & 2,319 & ISG & $332(14.3)$ & $177(53.3)$ & $99(29.8)$ \\
\hline Duzgun et $\mathrm{al}^{6}$ & Turkey & 180 & ISG & 7I (39.4) & $48(26.7)$ & $104(57.8)$ \\
\hline Wu et $\mathrm{al}^{7}$ & China & 766 & ISG & $93(12.1)$ & $4(4.3)$ & $78(83.9)$ \\
\hline Sagdiç et $\mathrm{al}^{8}$ & Turkey & 129 & ISG & $52(40.3)$ & $4(10)$ & $29(76)$ \\
\hline Davatchi et al $^{9}$ & Iran & 7,187 & Expert opinion & $553(9.1)$ & I 40 (2.3) & $399(6.6)$ \\
\hline Boura et $\mathrm{al}^{10}$ & Greece & 36 & ISG & NA & $5(13.9)$ & NA \\
\hline Mousa et al" & Kuwait & 29 & O’Duffy & $10(34.4)$ & $7(24.1)$ & $3(10.3)$ \\
\hline Yücel et al'2 & Turkey & 231 & ISG & $37(16)$ & $37(16)$ & NA \\
\hline Pipitone et $\mathrm{al}^{13}$ & Italy & 137 & ISG & $42(30.7)$ & $15(10.9)$ & $28(2 \mathrm{I})$ \\
\hline Balta et $\mathrm{al}^{14}$ & Turkey & 521 & ISG & $30(5.7)$ & II (2.I) & $16(3.6)$ \\
\hline Calamia et $\mathrm{al}^{15}$ & USA & 13 & ISG & $3(23)$ & I (8) & $2(15)$ \\
\hline Desbois et $\mathrm{al}^{16}$ & France & 807 & ISG & NA & $26(4.4)$ & $560(95.6)$ \\
\hline
\end{tabular}

Abbreviations: BD, Behçet's disease; DVT, deep venous thrombosis; ISG, International Study Group for Behçet's Disease; NA, not available; SVT, superficial venous thrombosis. 
estimated in studies. Finally, SVT could be misdiagnosed as other dermatological features such as cutaneous polyarteritis nodosa and erythema nodosum. ${ }^{19,22}$

In a retrospective study, Coskun et al found that erythema nodosum-like lesions and SVT could be predictive factors for visceral manifestations. They concluded that patients with those lesions should be closely monitored in terms of major organ involvement. ${ }^{17}$ Nevertheless, these findings should be validated in large prospective studies. Moreover, in a retrospective histopathological study, the presence of phlebitis in erythema nodosum-like lesions was associated with severe visceral involvement. ${ }^{23}$ In another study, erythema nodosum was found to be a prognostic factor for the development of SVT. ${ }^{24}$ In some cases, the clinical distinction between the two lesions would be challenging. ${ }^{19}$ SVT may occur in isolation or coexist concomitantly with DVT. Although there are no guidelines for the management of SVT associated with BD, anticoagulation therapy using enoxaparin has been used successfully in some reported cases. ${ }^{25}$

\section{Conclusion}

SVT is a common manifestation of vascular BD. The diagnosis is primarily clinical, based on three main signs: erythema and tenderness in the distribution of a superficial vein, and the identification of a palpable cord. Duplex ultrasound should be performed on both the affected and contralateral limb to rule out a concomitant DVT.

SVT has a dual importance in prognosis. First, it should raise the suspicion of concomitant deep venous and/or arterial involvement. Second, it may predict the development of future serious visceral manifestations. Therefore, both shortterm and long-term clinical monitoring should be performed in patients with SVT.

\section{Ethics approval}

Institutional approval was not required to publish this case report.

\section{Disclosure}

The authors report no conflicts of interest in this work.

\section{References}

1. Sakane T, Takeno M, Suzuki N, Inaba G. Behçet's disease. $N$ Engl J Med. 1999;341(17):1284-1291.

2. Kural-Seyahi E, Fresko I, Seyahi N, et al. The long-term mortality and morbidity of Behçet syndrome: a 2-decade outcome survey of 387 patients followed at a dedicated center. Medicine. 2003;82(1):60-76.
3. Ghembaza ME, Bouabdallah N, Lounici A. Behçet disease in Western Algeria. Med Sante Trop. 2017;27(1):101-104.

4. Owlia MB, Mehrpoor G. Behcet's disease: new concepts in cardiovascular involvements and future direction for treatment. ISRN Pharmacol. 2012;2012(6):1-13.

5. Sarica-Kucukoglu R, Akdag-Kose A, Kayabalı M, et al. Vascular involvement in Behçet's disease: a retrospective analysis of 2319 cases. Int J Dermatol. 2006;45(8):919-921.

6. Düzgün N, Ates, A, Aydintug OT, Demir O, Olmez U. Characteristics of vascular involvement in Behçet's disease. Scand J Rheumatol. 2006;35(1):65-68.

7. Wu X, Li G, Huang X. Behçet's disease complicated with thrombosis: a report of 93 Chinese cases. Medicine. 2014;93(28):e263.

8. Sağdiç K, Ozer ZG, Saba D, Türe M, Cengiz M. Venous lesions in Behçet's disease. Eur J Vasc Endovasc Surg. 1996;11(4):437-440.

9. Davatchi F, Chams-Davatchi C, Shams H, et al. Adult Behcet's disease in Iran: analysis of 6075 patients. Int J Rheum Dis. 2016;19(1):95-103.

10. Boura P, Tselios K, Skendros P. Adamantiades-Behcet disease (ABD) in northern Greece patients: experience from a single center. Hippokratia. 2007;11(4):210.

11. Mousa AR, Marafie AA, Rifai KM, Dajani AI, Mukhtar MM. Behçet's disease in Kuwait, Arabia. A report of 29 cases and a review. Scand $J$ Rheumatol. 1986;15(3):310-332.

12. Yücel A, Sönmezoğlu Marakli S, Aksungur VL, Uzun S, Sertdemir Y, Alpsoy E. Clinical evaluation of Behçet's disease: a five year follow-up study. J Dermatol. 2005;32(5):365-370.

13. Pipitone N, Boiardi L, Olivieri I, et al. Clinical manifestations of Behçet's disease in 137 Italian patients: results of a multicenter study. Clin Exp Rheumatol. 2004;22(6 Suppl 36):S46-S51.

14. Balta I, Akbay G, Kalkan G, Eksioglu M. Demographic and clinical features of 521 Turkish patients with Behçet's disease. Int J Dermatol. 2014;53(5):564-569.

15. Calamia KT, Wilson FC, Icen M, Crowson CS, Gabriel SE, Kremers HM. Epidemiology and clinical characteristics of Behçet's disease in the US: a population-based study. Arthritis Rheum. 2009;61(5):600-604.

16. Desbois AC, Wechsler B, Resche-Rigon M, et al. Immunosuppressants reduce venous thrombosis relapse in Behçet's disease. Arthritis Rheum. 2012;64(8):2753-2760.

17. Coskun B, Oztürk P, Saral Y. Are erythema nodosum-like lesions and superficial thrombophlebitis prodromal in terms of visceral involvement in Behcet's disease? Int J Clin Pract. 2005;59(1):69-71.

18. Decousus H, Epinat M, Guillot K, Quenet S, Boissier C, Tardy B. Superficial vein thrombosis: risk factors, diagnosis, and treatment. Curr Opin Pulm Med. 2003;9(5):393-397.

19. Seyahi E, Yurdakul S. Behçet's Syndrome and Thrombosis. Mediterr J Hematol Infect Dis. 2011;3(1):e2011026.

20. Kawakami T, Yamazaki M, Mizoguchi M, Soma Y. Antiphosphatidylserine-prothrombin complex antibodies in 3 patients with Behçet disease involving superficial vein thrombophlebitis. Arch Dermatol. 2009;145(2):171-175.

21. Kalodiki E, Stvrtinova V, Allegra C. Superficial vein thrombosis: a consensus statement (vol 31,pg 203, 2012). Int Angiol. 2012;31(4):405-405.

22. Chen KR. The misdiagnosis of superficial thrombophlebitis as cutaneous polyarteritis nodosa: features of the internal elastic lamina and the compact concentric muscular layer as diagnostic pitfalls. $\mathrm{Am} \mathrm{J}$ Dermatopathol. 2010;32(7):688-693.

23. Misago N, Tada Y, Koarada S, Narisawa Y. Erythema nodosum-like lesions in Behçet's disease: a clinicopathological study of 26 cases. Acta Derm Venereol. 2012;92(6):681-686.

24. Zouboulis CC, Kötter I, Djawari D, et al. Epidemiological features of Adamantiades-Behçet's disease in Germany and in Europe. Yonsei Med J. 1997;38(6):411-422.

25. Uva L, Miguel D, Pinheiro C, Filipe P, Freitas JP. Mucocutaneous manifestations of Behçet's disease. Acta Reumatol Port. 2013;38(2):77-90. 


\section{Publish your work in this journal}

The Journal of Vascular Diagnostics and Interventions is an international, peer-reviewed journal of diagnostics, focusing on non invasive vascular investigation methods involved in the evaluation of vascular diseases. The journal is committed to the rapid publication in the fields of vascular diseases. Original research, review, case reports, expert opinion and commentaries are all considered for publication. The manuscript management system is completely online and includes a very quick and fair peer-review system, which is all easy to use. Visit http://www.dovepress.com/testimonials.php to read real quotes from published authors.

Submit your manuscript here: https://www.dovepress.com/journal-of-vascular-diagnostics-journal 